\title{
DIASTEREOSELECTIVE SYNTHESIS OF (8E,10Z)-TETRADECA-8,10-DIENAL, THE SEXUAL PHEROMONE OF THE HORSE-CHESTNUT LEAF-MINER Cameraria ohridella (LEPIDOPTERA: GRACILLARIIDAE)
}

\author{
IULIANA VASIAN ${ }^{\mathrm{a}^{*}}$, TEODORA FLORIAN ${ }^{\mathrm{b}}$, ALEXANDRINA NAN $^{\mathrm{c}}$, \\ EMESE GAL ${ }^{d}$, MONICA GORGAN $^{\mathrm{a}}$, STTEFANIA MARIA TÖTÖS ${ }^{a}$, \\ VASILE FLORIAN ${ }^{\mathrm{b}}$, IÓN OLTEAN ${ }^{\mathrm{b}}$
}

\begin{abstract}
Versatile classical and modern methods for a new synthesis of $(8 E, 10 Z)$-tetradeca-8,10-dienal based on Sonogashira cross-coupling, Cahiez-Fürstner reaction as well as other reactions using palladium, iron or copper as catalysts were described. We designed two ways employing two different strategies one of that involves an E-reduction and the other a Zreduction with crucial importance in terms of diastereoselective synthesis. From the variously formulated pheromone baits, the one containing only the active isomer showed superior activity compared to the mixture of all isomers of 8,10-tetradecandienal. The synthesis of the pure $E, Z$ diastereoisomer allowed to clarify their structure-bioactivity relationships to reveal the diversity in the stereochemical aspects of pheromone communications.
\end{abstract}

Keywords: Cameraria ohridella, (8E,10Z)-tetradeca-8,10-dienal, Pheromone, Lure, Field Tests

\section{INTRODUCTION}

Cameraria ohridella (Lepidoptera: Gracillariidae), the horse-chestnut leaf miner is a micro moth whose larvae create mines in the leaves of horse chestnut trees Aesculus hippocastanum L., and it was discovered in Macedonia by Deschka and Dimic around the Ohrid Lake (Macedonia) as early as 1986 [1].

a Babeș-Bolyai University, Raluca Ripan Institute for Research in Chemistry, Pheromones Production Centre, Fântânele 30, 400084, Cluj-Napoca, Romania.

$b$ University of Agricultural Sciences and Veterinary Medicine Cluj-Napoca, Faculty of Agriculture, Department of Entomology, 3-5 Mănăştur Street, 400372, Cluj-Napoca, Romania.

c National Institute for Research and Development of Isotopic and Molecular Technologies, 67-103 Donat Str., 400293 Cluj-Napoca, Romania.

d Babeş-Bolyai University, Faculty of Chemistry and Chemical Engineering, 11 Arany Janos str., RO-400028, Cluj-Napoca, Romania.

*Corresponding author: iuliana.vasian@ubbcluj.ro, iulianavasian@yahoo.com. 
At that time, they considered this area being the place of origin of this species. Nevertheless, according to the later literature data, its authentic origin was Asian [2]. It was then spread throughout Europe after 1985 and was first reported in Romania in 1998 in Lovrin area [3].

$(8 E, 10 Z)$-Tetradeca-8,10-dienal has been identified by Svatoš, 1999 [4] and Kalinova, 2003 [5] with EAD activity experiments as the female sex pheromone of the horse chestnut leaf miner Cameraria ohridella (Lepidoptera, Gracillariidae).

From synthetic point of view, some publications have reported the synthesis of (8E,10Z)-tetradeca-8,10-dienal such as Hoskovec [6], Francke [7], Marcia de Figueiredo [8], Gânscă [9]. Recently, a method of stereoselective synthesis of $(8 E, 10 Z)$-tetradeca-8,10-dienal has been developed by Chourreu, 2020 [10] with good results based on an iron-catalyzed Kumada cross-coupling. The most important syntheses from the point of the strategy were reported by Svatoš [4] and Grodner [11]. The first synthesis of (8E,10Z)-tetradeca-8,10dienal achieved by Svatoš employs a $\mathrm{C} 7+\mathrm{C} 2+\mathrm{C} 5$ carbon chain units strategy. $(E)$-14-(tert-butoxy)tetradec-6-en-4-yne, the key intermediate in this synthesis, was prepared using Sonogashira cross-coupling reaction [12]. The synthesis by Grodner [11] involves a $\mathrm{C} 5+\mathrm{C} 5+\mathrm{C} 4$ carbon chain units strategy, the stereospecific introduction of double bonds being achieved through the same methodology based on the $\mathrm{Pd}(0)$-catalysed cross-coupling between suitable halo alkene and the known 1-pentynylmagnesium bromide.

Most of the syntheses described in the literature involve a reduction reaction with boranes or $\mathrm{LiAlH}_{4}$ [13]. Any attempt to reproduce the described syntheses has conducted to low yields and low selectivity. When $\mathrm{LiAlH}_{4}$ was used, a mixture of 4 isomers in different proportions was formed. In this paper we described a versatile method for the synthesis of $(8 E, 10 Z)$-tetradeca-8,10dienal which can be successfully apply at large scale for production purposes.

Herein, we report a practical method for the synthesis of $(8 E, 10 Z)$ tetradeca-8,10-dienal (1) based on Sonogashira and Cahiez-Fürstner crosscoupling reaction using palladium, iron and copper catalysts, to obtain 1 as a single diastereoisomer in large quantities.

\section{RESULTS AND DISCUSSION}

\section{Synthesis of 8,10-tetradecadienal (1') as a mixture of all its four diastereomeric forms}

We first synthesized 8,10-tetradecadienal (1) as a mixture of four geometric diastereomers $(E, Z),(E, E),(Z, E)$ and $(Z, Z)$. This synthesis followed a $\mathrm{C} 7+\mathrm{C} 2+\mathrm{C} 2+\mathrm{C} 3$ carbon chain strategy. 1,7-Heptanediol was brominated in 
the presence of $48 \%$ aq. $\mathrm{HBr}$ (yield $79 \%$ ) followed by the protection of the hydroxyl group with DHP (3,4-dihydro-2H-pyran) to give 2-(9-bromoheptyloxy)tetrahydro-2H-pyran (3) in $83 \%$ yield (Scheme 1) [14].

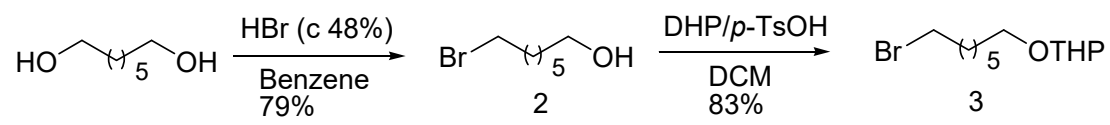

Scheme 1. Synthesis of 2-(9-bromoheptyloxy)-tetrahydro-2H-pyran (3)

2-(9-Bromoheptyloxy)-tetrahydro-2H-pyran (3) was coupled with commercial lithium acetylene ethylenediamine complex to give 2-(dec-9ynyloxy)-tetrahydro- $2 \mathrm{H}$-pyran (4) in $90 \%$ yield [15]. The Sonogashira crosscoupling reaction of 2-(dec-9-ynyloxy)-tetrahydro-2H-pyran (4) with 5 equivalents of commercial (Z)-1,2-dichloroethene in the presence of a catalytic amount of $\mathrm{Pd}(\mathrm{PPh} 3) 3 \mathrm{Cl} 2$, Cul and piperidine as base in THF afforded 2-[(Z)-11-chloroundec-10-en-8-ynyloxy]-tetrahydro-2H-pyran (5) in $67 \%$ yield and high isomeric purity (>95\% by GC) (Scheme 2 ).

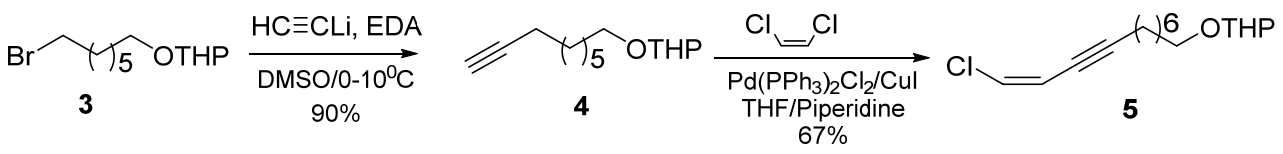

Scheme 2. Synthesis of 2-[(Z)-11-Chloroundec-10-en-8-ynyloxy]-tetrahydro-2H-pyran (5)

Next, the 2-[(Z)-11-chloroundec-10-en-8-ynyloxy]-tetrahydro-2H-pyran (5) was alkylated with propyl magnesiumbromide through a Cahiez-Fürstner cross-coupling reaction $[16,17]$ to provide $2-[(Z)$-tetradec-10-en-8-ynyloxy]tetrahydro-2 $\mathrm{H}$-pyran (7) in $75 \%$ yield. Thus, the entire fourteen carbon skeleton of the pheromone (1) has been achieved (Scheme 3).

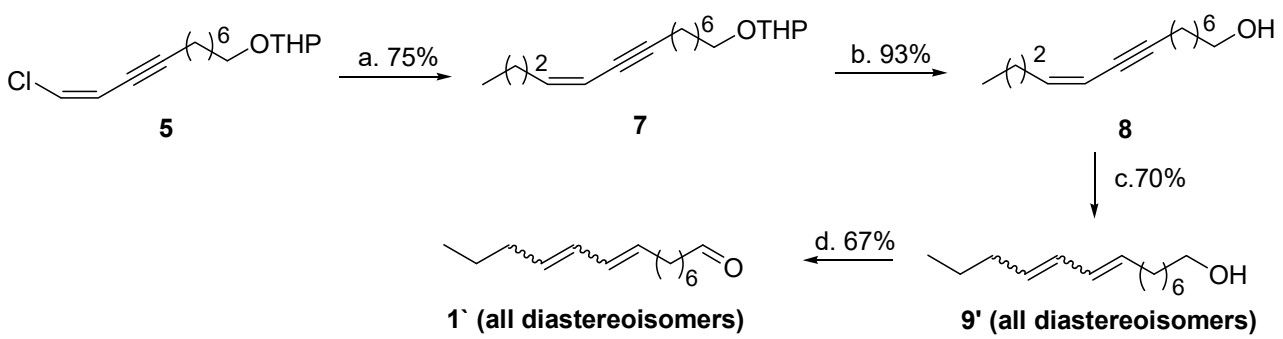

Scheme 3. Synthesis of 8,10-tetradecadienal (1). Reagents and catalysts:

a) 1. $n-\mathrm{Pr}-\mathrm{Br}(6), \mathrm{Mg}$ (1.2 eq.), $\mathrm{I}_{2}$, THF, reflux $2 \mathrm{~h} ; n-\mathrm{PrMgBr}$ was added to a solution of $\mathrm{Fe}(\mathrm{acac})_{3}$ (0.01 eq.), NMP, THF, b) p-TsOH (0.01 eq.), $\mathrm{MeOH}$; c) $\mathrm{LiAlH}_{4}$ (4 eq.), diglyme, $125-130^{\circ} \mathrm{C}, 4 \mathrm{~h}$; d) PCC (1.35 eq.), DCM, r.t., $4 \mathrm{~h}$ 
Deprotection of $(Z)$-enynol 7 after Boom's procedure [18] ( $p$-TsOH as catalyst) in methanol gave (Z)-tetradec-10-en-8-yn-1-ol (8) in $93 \%$ yield.

The (Z)-enynol 8 was reduced to the corresponding diene 9' according to the method of Rossi [13], with $\mathrm{LiAlH}_{4}$ in diglyme at $125-130^{\circ} \mathrm{C}$, to give a mixture of four isomers. Thus, it has been observed that the (Z)-double bond at position 10 of the enynol undergoes isomerization to the more stable $E$ diastereoisomer to give $(8 E, 10 E)$-tetradeca-8,10-dien-1-ol. The identification of isomers was assumed based on the literature data [4] and GC-MS analysis. Thus the mixture of 9' consisted of $43 \%$ of (Z,E), $29 \%$ (E,Z), $9 \%(Z, Z)$ and $19 \%(E, E), R T(Z E, E Z, Z Z, E E)=17.42,17.61,17.71,17.88$. The isomeric compounds thus obtained were oxidized with PCC (pyridinium chlorochromate) [19] in $\mathrm{CH}_{2} \mathrm{Cl}_{2}$ to the corresponding aldehydes 1' with a diastereomeric ratio, $Z E: E Z: Z Z: E E=49: 27: 7: 17$, identified by $G C$ analysis with retention time, RT $(Z E, E Z, Z Z, E E)=16.51,16.72,16.82,16.99$. (Scheme 3) [20].

The ratio of diastereoisomers was determined by GC-MS (Figure 1) and the presence of isomers mixture was confirmed by NMR analysis (Figure 3). The identification of the diastereoisomers was assumed based on the studies of Svatoš [4] and Kalinova [5].

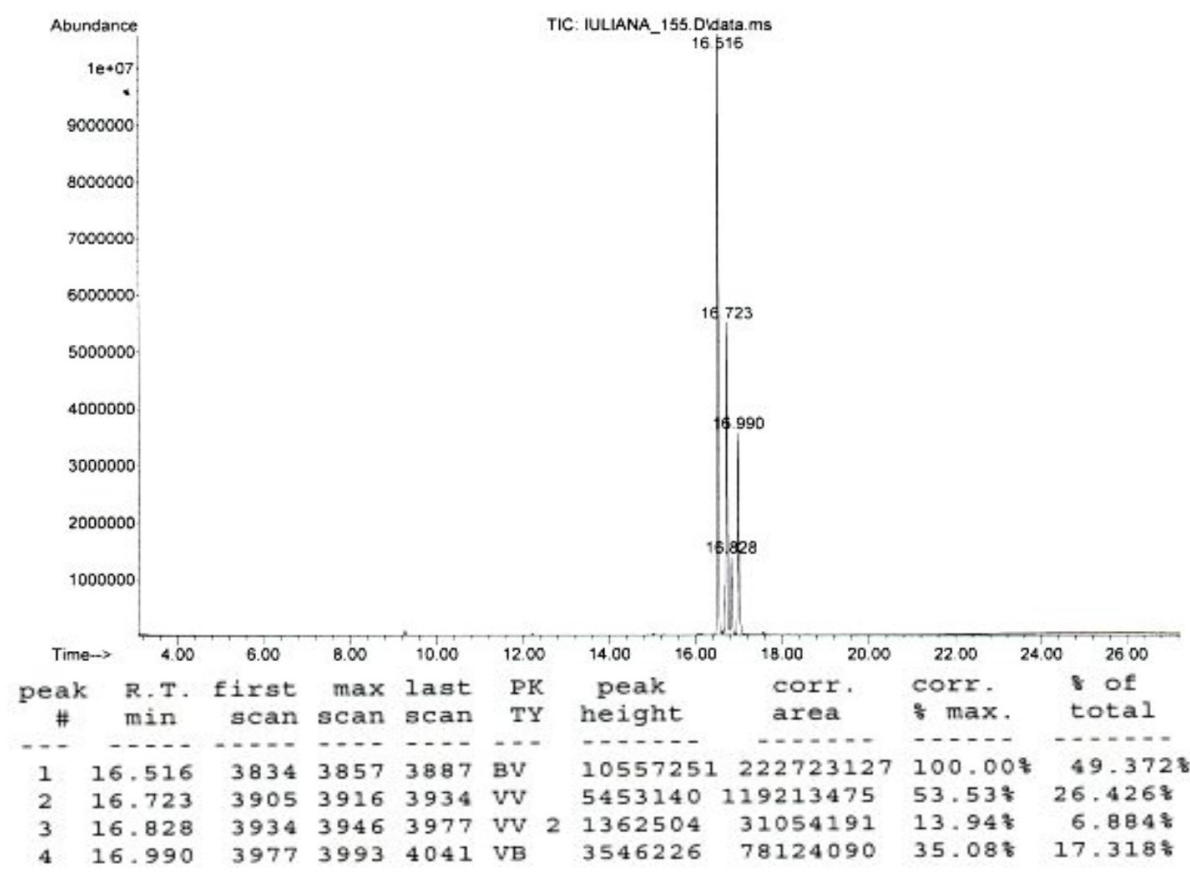

Figure 1. GC chromatogram of synthesized 8,10-tetradecadienal (1') as a mixture of all four diastereomeric forms 


\section{Synthesis of $(8 E, 10 Z)$-tetradeca-8,10-dienal (1)}

We have succeed to develop a very reliable method to synthesize the pure (8E,10Z)-Tetradeca-8,10-dienal (1) diastereoisomer, following a $\mathrm{C} 5+\mathrm{C} 2+\mathrm{C} 7$ carbon chain strategy. The key step was the stereoselective cisreduction of the triple bond by $\mathrm{H}_{2} / \mathrm{P}-1 \mathrm{Ni}$ boride according to the Brown method [21]. Borane reduction [22] led to a degradation of the compound in the presence of acetic acid. In our case the reduction with borane of $400 \mathrm{mg}$ of $(E)$-enynol 8 gave only $90 \mathrm{mg}(22.5 \%$ yield) of the corresponding diene $\mathbf{9}$.

The synthesis method of the pure $(8 E, 10 Z)$-tetradeca-8,10-dienal (1) diastereoisomer also used protected bromide compound 3 . In order to avoid the $E$-reduction with lithium aluminium hydride, which gave an isomeric mixture, we have decided to employ $(E)$-cloroenyne 12 as coupling partner. This was obtained in good yield and high stereoisomeric purity by Sonogashira cross-coupling reaction of the 1-pentyne (11) with commercial trans-1,2-dichloroethylene in the presence of $\mathrm{Pd}\left(\mathrm{PPh}_{3}\right)_{3} \mathrm{Cl}_{2}$ and $\mathrm{Cul}$ as catalysts in piperidine in THF (Scheme 4).

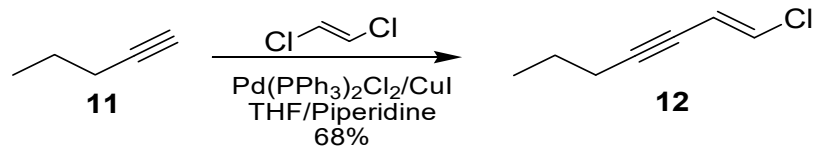

Scheme 4. Synthesis of (E)-1-chlorohept-1-en-3-yne (12)

Further, the alkylation of $(E)$-chloroenyne 12 with the corresponding Grignard reagent, obtained from 2-(9-bromoheptyloxy)-tetrahydro- $2 \mathrm{H}$-pyran (3) and $\mathrm{Mg} / \mathrm{I} 2 / \mathrm{THF}$, in the presence of iron catalyst, after Cahiez crosscoupling reaction [16], afforded $(E)$-enyne 13 in moderate yield and high diastereoisomeric purity. Thus, the entire skeleton of fourteen carbon atoms has been reached after a $\mathrm{C} 5+\mathrm{C} 2+\mathrm{C} 7$ chain strategy (Scheme 5).
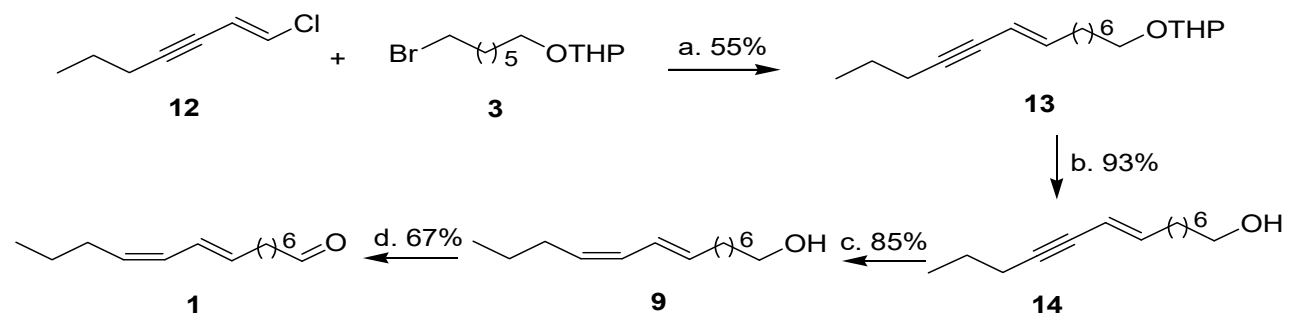

Scheme 5. Synthesis of (8E,10Z)-Tetradeca-8,10-dienal (1). Reagents and conditions: a. $\mathrm{Mg}$ (1.2 eq.), $\mathrm{I}_{2}, \mathrm{THF}$, reflux, $2 \mathrm{~h}$, Grignard formed was added to a solution of $\mathrm{Fe}(\mathrm{acac})_{3}(0,01$ eq.), NMP, THF, r.t.; b. $p$-TsOH, $\mathrm{MeOH}$, r.t., over night; c. $\mathrm{H}_{2} / \mathrm{P}-1 \mathrm{Ni}$ boride, 1 atm., r.t., $4 \mathrm{~h}$; d. PCC (1.35 eq.), DCM, r.t., $4 \mathrm{~h}$ 
IULIANA VASIAN, TEODORA FLORIAN, ALEXANDRINA NAN, EMESE GAL, MONICA GORGAN, ȘTEFANIA MARIA TÖTÖS, VASILE FLORIAN, ION OLTEAN

After deprotection of 2-((E)-Tetradec-8-en-10-ynyloxy)-tetrahydro2H-pyran (13), the prepared (E)-Tetradec-8-en-10-yn-1-ol (14) was hydrogenated in the presence of $\mathrm{H}_{2} / \mathrm{P}-1 \mathrm{Ni}$ boride [21] to the corresponding $(8 E, 10 \mathrm{Z})$ tetradeca-8,10-dienol (9) in high yield (85\%) and high stereoisomeric purity (> 95\% from GC-MS analysis). Corey oxidation [19] of (8E,10Z)-tetradeca8,10-dienol (9) with PCC (pyridinium chlorochromate) in $\mathrm{CH}_{2} \mathrm{Cl}_{2}$ gave the desired pheromone component $(8 E, 10 Z)$-tetradeca-8,10-dienal (1) in good yield $(67 \%)$ and high diastereoisomeric purity (> 99\% from GC-MS analysis Figure 2).

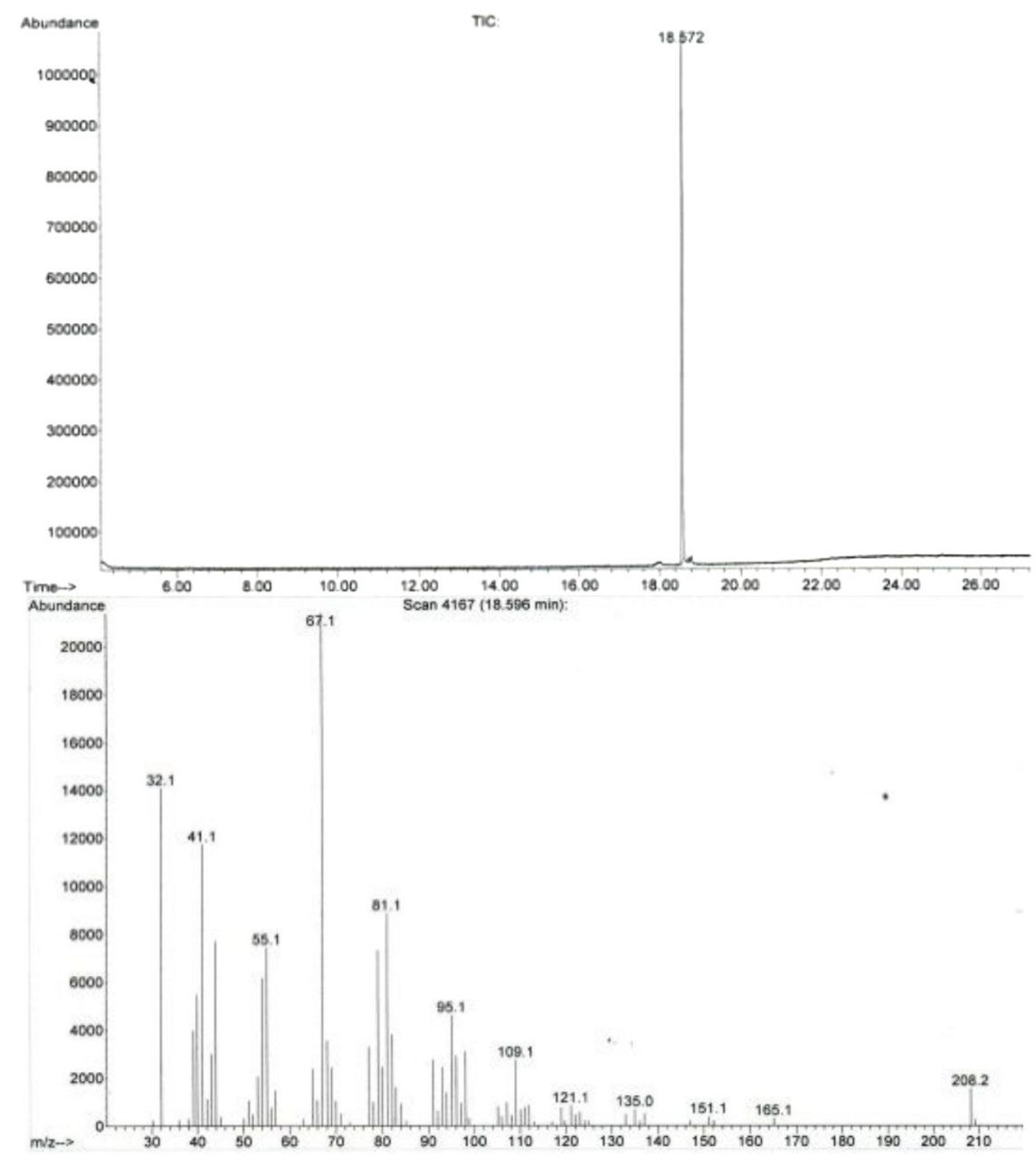

Figure 2. GC-MS analysis of (8E,10Z)-tetradeca-8,10-dienal (1) 
The compounds 5,13 and 14 obtained by Sonogashira coupling reaction, respectively by Grignard reaction, were identified by GC-MS analysis, and the yield of the reaction was calculated from the obtained chromatograms.

Purification of 2-((E)-Tetradec-8-en-10-ynyloxy)-tetrahydro-2H-pyran (13) and (E)-Tetradec-8-en-10-yn-1-ol (14) is quite difficult due to the presence of by-products, for this reason these intermediates were used without any purification.

The ${ }^{1} \mathrm{H}-\mathrm{NMR}$ spectrum of the pure isomer (1) has clear signals for the four dienic protons (b), while the signals in the mixture of isomers are overlapped (a) due to the presence of all four isomers with different intensity (Figure 3).

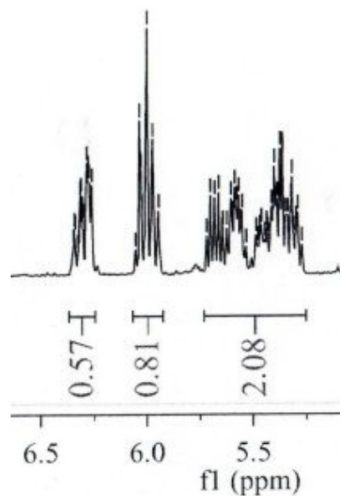

a) Mixture of diastereoisomer $1^{\text {' }}$

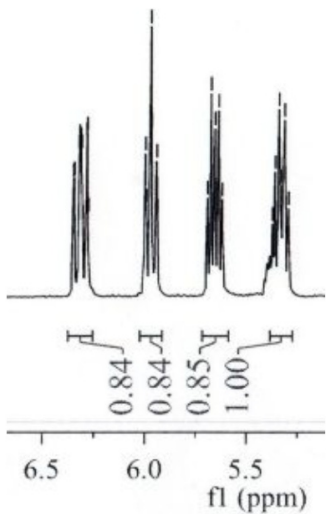

b) Pure (8E,10Z)-tetradeca-8,10-dienal (1)

Figure 3. Fragment of ${ }^{1} \mathrm{H}-\mathrm{NMR}\left(400 \mathrm{MHz}, \mathrm{CDCl}_{3}\right) \delta$ (ppm) 5.35-6.29 of 8,10-tetradecadienal (1') and (8E,10Z)-tetradeca-8,10-dienal (1), 4 protons of the conjugated diene

Although the structure of the compounds ZE:EZ:ZZ:EE was elucidated by physico-chemical analysis [4], and the action of these was tested in the wind tunnel by Svatoš [4], the field trials (experiments) in nature may differ from those in the laboratory.

\section{The efficiency of pheromone variants in field trials for capturing adults of Cameraria ohridella}

In order to obtain a new formulation of the pheromone we have developed three pheromone variants, which have been tested in the field experiments. Variant F1 was loaded with $0.1 \mathrm{mg}$ of isomers mixture, variant 
$\mathrm{F} 2$ with $0.5 \mathrm{mg}$ and variant $\mathrm{F} 3$ with $0.1 \mathrm{mg}$ of pure active substance (F2 contains the same quantity of active as F3). The field experiments revealed that the variant F3 loaded with $0.1 \mathrm{mg}$ of pure active pheromone has a net superior attractiveness to the other variants. The increase in the concentration of isomers has reduced the attractiveness of the Cameraria males. From the Svatoš analysis [4], it can be observed that the $(Z, Z)$ isomer may have a negative effect on the pheromonal bait, thus assuming that the increase in the concentration of this in excess can have an antagonistic effect, as shown in Table 1, a decrease by half of F2 catches with $0.5 \mathrm{mg} /$ lure compared to the variant $\mathrm{F} 1$ with the same compounds but with $0.1 \mathrm{mg}$ isomers/lure (Figure 4).

Table 1. The captures of Cameraria ohridella males for blends F1, F2, F3

\begin{tabular}{|c|c|c|c|c|c|c|c|}
\hline \multirow{2}{*}{ Repetition } & \multirow{2}{*}{$\begin{array}{c}\text { Variant } \\
\text { formulation* }\end{array}$} & \multicolumn{5}{|c|}{$\begin{array}{c}\text { Capture no. of Cameraria ohridella } \\
\text { males }\end{array}$} & \multirow{2}{*}{$\begin{array}{l}\text { TOTAL } \\
\text { No. of } \\
\text { males }\end{array}$} \\
\hline & & $\begin{array}{l}4.07 \\
2018\end{array}$ & $\begin{array}{l}23.07 \\
2018\end{array}$ & $\begin{array}{l}31.07 \\
2018\end{array}$ & $\begin{array}{l}4.09 \\
2018\end{array}$ & $\begin{array}{l}24.09 \\
2018\end{array}$ & \\
\hline \multirow{3}{*}{ R1 } & $\begin{array}{l}\mathrm{F} 1-0,1 \mathrm{mg} \text { isomeric } \\
\text { mixture }\end{array}$ & 1320 & 1628 & 2100 & 2000 & 227 & 7275 \\
\hline & $\begin{array}{l}\mathrm{F} 2-0,5 \mathrm{mg} \text { isomeric } \\
\text { mixture }\end{array}$ & 548 & 408 & 311 & 2849 & 11 & 4127 \\
\hline & $\mathrm{F} 3-0,1 \mathrm{mg}$ pure isomer & 2600 & 3979 & 2700 & 6300 & 244 & 15823 \\
\hline \multirow{3}{*}{ R2 } & $\begin{array}{l}\mathrm{F} 1-0,1 \mathrm{mg} \text { isomeric } \\
\text { mixture }\end{array}$ & 2250 & 1790 & 1980 & 1260 & 57 & 7337 \\
\hline & $\begin{array}{l}\text { F2 - 0,5 mg isomeric } \\
\text { mixture }\end{array}$ & 528 & 835 & 1420 & 2080 & 67 & 4930 \\
\hline & F3 - 0,1 mg pure isomer & 2300 & 3778 & 2840 & 5160 & 92 & 14170 \\
\hline
\end{tabular}

${ }^{*}$ The variant formulation of Cameraria ohridella blend: $\mathrm{F} 1=0,1 \mathrm{mg} / \mathrm{bait}$ isomeric mixture, $\mathrm{F} 2=0,5 \mathrm{mg} / \mathrm{bait}$ isomeric mixture, $\mathrm{F} 3=0,1 \mathrm{mg} / \mathrm{bait}$ pure compound.

F1

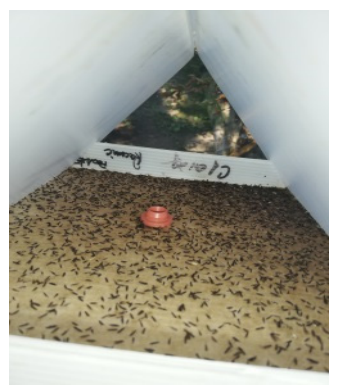

F2

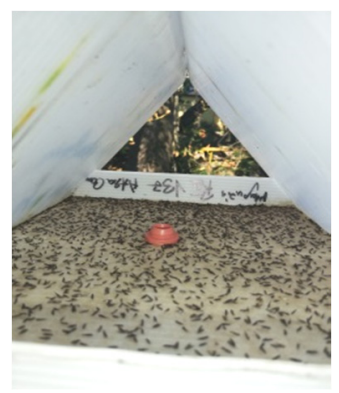

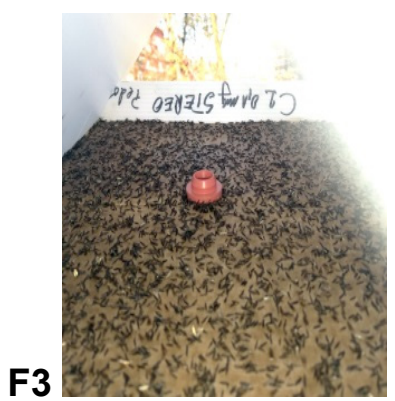

Figure 4. The catches of Cameraria ohridella in the traps of variants F1, F2, F3

The graph analysis presented in Figure $\mathbf{5}$ shows that there are significant differences between the three pheromone variants $(p=0.0003)$. However, the Duncan analysis shows that there are no significant differences 
between F1 and F2 assortment. Due to the fact that over $75 \%$ of the data recorded using pheromone variant F3 had higher values than the other two variants, this pheromone variant is significantly different from the other two variants.

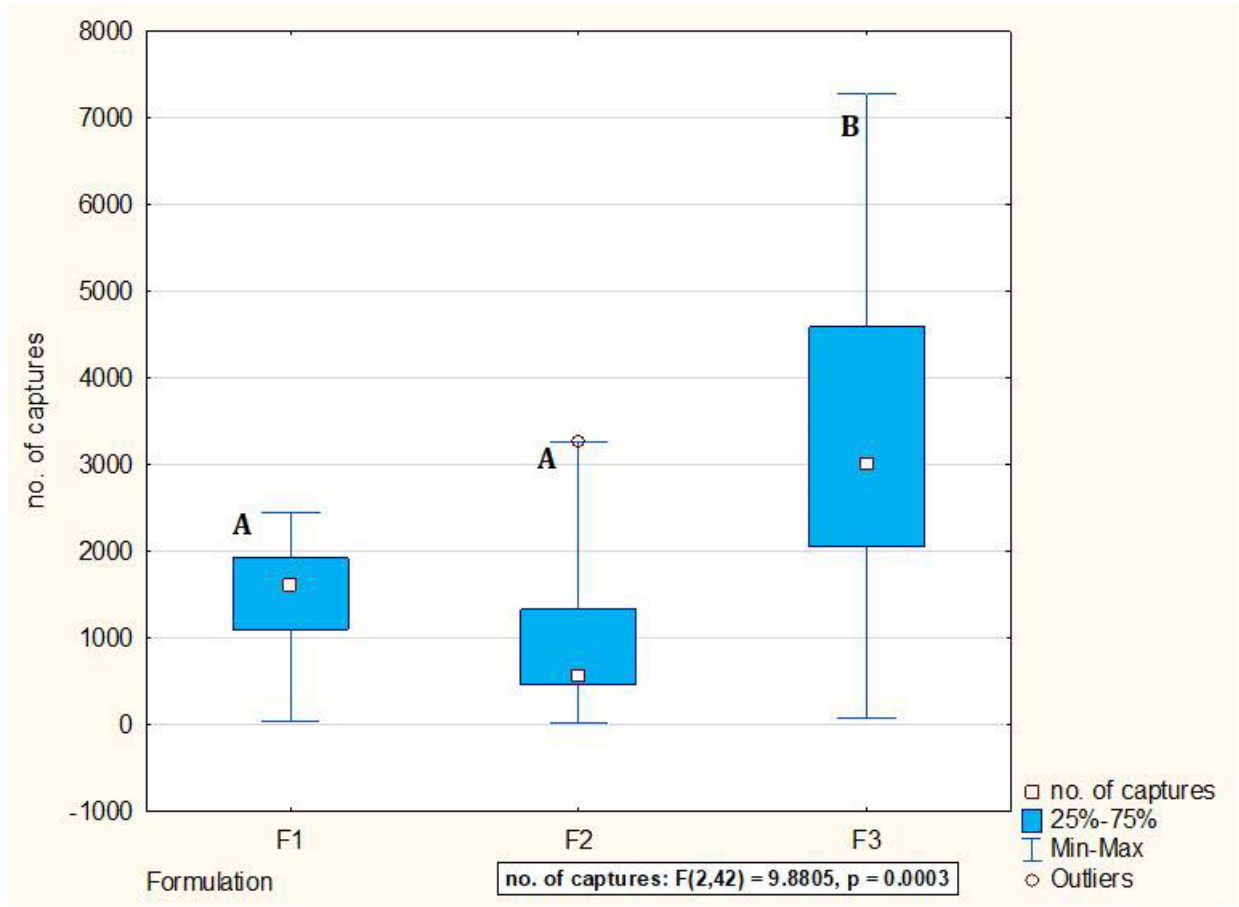

Figure 5. Pheromonal variants efficiency in capturing adult Cameraria ohridella

The records started on 04.07.2018 and were completed on 24.09.2018. There is a gradual increase in the average number of shots until the beginning of September and then in the third decade of captures it decreases greatly at just a few doses.

Compared to the average of the experiment, it can be seen that the number of catches in pheromone F3 exceeded this value at all observation data, except of course the last reading at which adult flight drops significantly (Figure 6).

There is a significant increase in catches, especially at the beginning of September. This is mainly due to the efficiency of pheromone variant F3 (Table 1 and Figure 7). 
IULIANA VASIAN, TEODORA FLORIAN, ALEXANDRINA NAN, EMESE GAL, MONICA GORGAN, ȘTEFANIA MARIA TÖTÖS, VASILE FLORIAN, ION OLTEAN

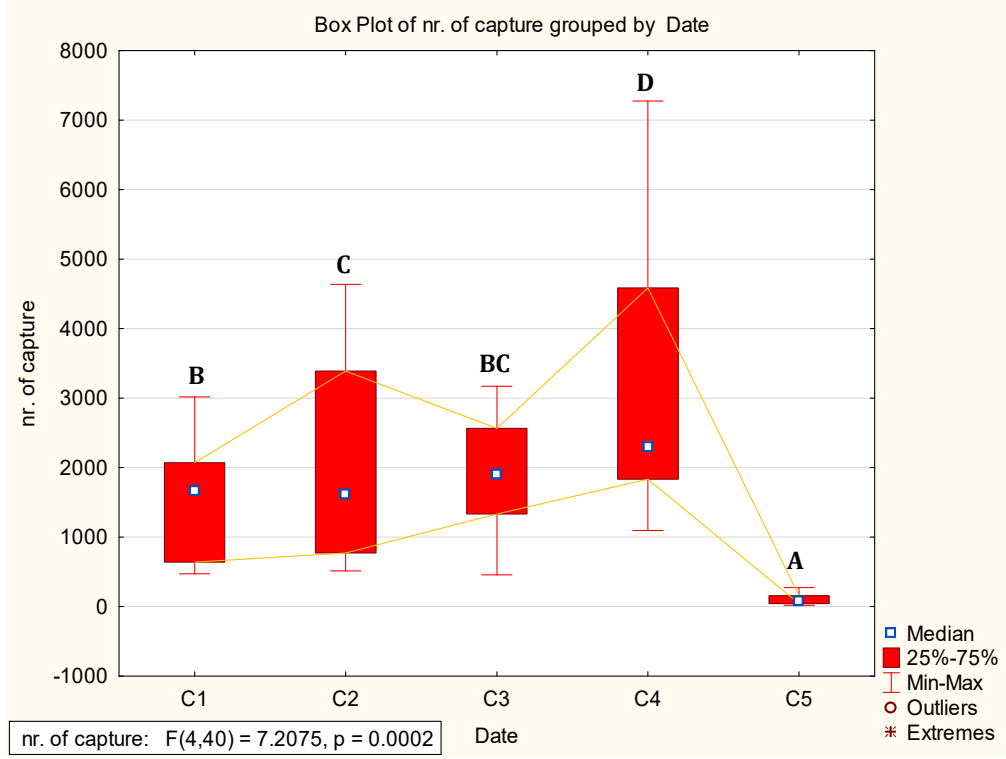

Figure 6. Evolution of catches depending on the date on which they were made

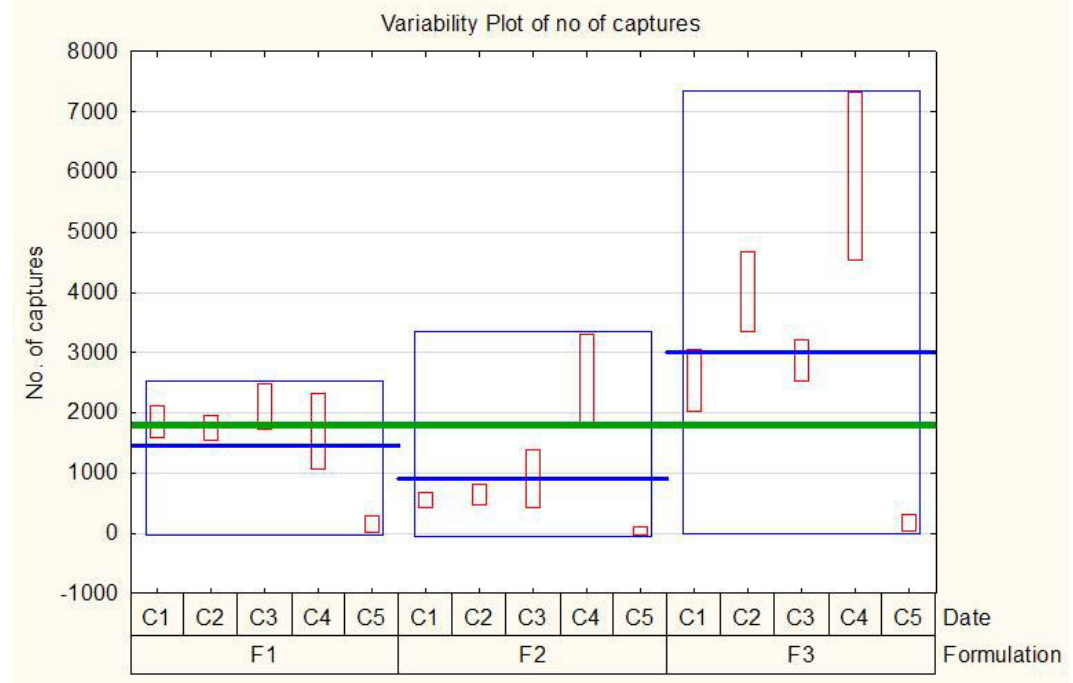

= Group Means

no of captures: $F(14,30)=26.652, p=0.0000$

Figure 7. Number of pheromone-captured digits and reading data 
The effectiveness of pheromone F2 is only demonstrated at the time of the maximum flight of these pests. On average, this pheromone has been shown to have lower efficiency than pheromone $\mathrm{F} 1$, with other readings being very small.

\section{CONCLUSIONS}

In conclusion, in this research work we describe a versatile stereoselective method for the synthesis of pure $(8 E, 10 Z)$-tetradeca-8,10dienal using cross-coupling reactions in the key steps after a $\mathrm{C} 5+\mathrm{C} 2+\mathrm{C} 7$ carbon chain strategy and a Z-reduction with crucial importance. The described methods were successfully applied on a large scale for production purposes in our production plant. Based on the field experiments, a new formulation of the pheromone lure was obtained for the product atraCAM, which employ a much smaller amount of the pheromone.

\section{EXPERIMENTAL SECTION}

Synthesis. All reaction products were analysed by GC-MS and NMR spectroscopy. Electron impact $(70 \mathrm{eV})$ mass spectra were obtained on Hewlett-Packard MD 5972 GC-MS respectively on a GC-MS Shimadzu QP 2010 Plus instruments. GC analyses were performed on a Hewlett-Packard HP 5890 gas chromatograph. A HP-5MS capillary column $(30 \mathrm{~m} \times 0.25 \mathrm{~mm}$ $\mathrm{x} 0.33 \mu \mathrm{m})$ and helium gas were used for separations. ${ }^{1} \mathrm{H}-\mathrm{NMR}(400 \mathrm{MHz}$ or $600 \mathrm{MHz}$ ) and ${ }^{13} \mathrm{C}-\mathrm{NMR}(101 \mathrm{MHz}$ or $151 \mathrm{MHz})$ spectra were recorded at room temperature in $\mathrm{CDCl}_{3}$ on a Bruker Advanced $400 \mathrm{MHz} / 600 \mathrm{MHz}$ spectrometer, using the solvent line as reference. Thin layer chromatography (TLC) was performed on silica gel 60 F254 TLC plates purchased from Merck. Chemicals were purchased from Aldrich, Merck and Alfa Aesar and were used without further purification. All chemical reactions occurred in dry installations under argon stream.

Field tests. Different pheromone mixtures were tested for field activity. Delta traps, produced at the Pheromone Production Center of "Babes-Bolyai" University, "Raluca Ripan" Institute for Research in Chemistry, were used in the field trials. Red bromobutyl rubber septa $19 \mathrm{~mm}$, loaded with the desired semiochemical mixture of lure in $50 \mu \mathrm{l} n$-hexane solution and $0,1 \% \mathrm{BHT}$ (Butylated hydroxytoluene) were used for field trials. After loading, the solvent was allowed to evaporate in a hood at room 
temperature for $30-45 \mathrm{~min}$. Lures were wrapped in aluminium envelope and deposited in refrigerator until they were mounted in the field. The traps with pheromone were installed in different locations in the Cluj-Napoca area and in the experimental fields/park at University of Agricultural and Veterinary Medicine University. They were hung at crop canopy level $150 \mathrm{~cm}$ above ground level, checked every 5-7 days. The pheromone bait capsule was changed every 6 weeks. Statistical analyses of trap catches from each test were compared with Duncan analysis.

\section{Preparation of compound 2}

To a benzene $(300 \mathrm{~mL})$ solution containing 1,7-heptanediol $(11.00 \mathrm{~g}$, $83.33 \mathrm{mmol}$ ), $\mathrm{HBr}$ (1.2 eq., $48 \%$ aq., $8.09 \mathrm{~g}, 11.32 \mathrm{~mL}, 99.96 \mathrm{mmol}$ ) was added with vigorous stirring. The reaction mixture was azeotropically distilled using a Dean Stark trap to complete removal of water (about $10.55 \mathrm{ml}$ ). The reaction mixture was TLC checked and other $3.00 \mathrm{~mL} \mathrm{HBr}(48 \%$ aq.) was then added and the resulted solution was allowed to stand for about $5 \mathrm{~h}$. After cooling at rt, the reaction mixture was washed to neutrality with $7 \%$ aq. soln. $\mathrm{NaHCO}_{3} 50 \mathrm{~mL}$ ) then with water $(75 \mathrm{~mL})$ and, finally, with brine $\left.75 \mathrm{~mL}\right)$. The organic layer was dried over anh. $\mathrm{MgSO}_{4}$ and then evaporated to dryness under reduced pressure. Purification by flash column chromatography (silica gel, eluent $n$-hexane: $\mathrm{Et}_{2} \mathrm{O}=2: 1 \mathrm{v} / \mathrm{v}$, visualization with $\mathrm{H}_{2} \mathrm{SO}_{4}$ in ethanol, $R_{\mathrm{f}}$ $=0.68)$ gave the desired compound 7-bromoheptan-1-ol (2) $(12.9 \mathrm{~g}, 79 \%$ yield with respect to 1,7-heptanediol) as pure (>98\%) compound.

7-Bromoheptan-1-ol 2. Incolor liquid. 1H-NMR (400 MHz, CDCl3): $\delta$ (ppm) $3.60(\mathrm{t}, 3 \mathrm{JH}, \mathrm{H}=6.0 \mathrm{~Hz}, 2 \mathrm{H}), 3.30(\mathrm{t}, 3 \mathrm{JH}, \mathrm{H}=6.0 \mathrm{~Hz}, 2 \mathrm{H}), 3.10(\mathrm{br} \mathrm{s}, 1 \mathrm{H}$, $-\mathrm{OH}$ ), 1.80-2.10 (overlapped signals, $4 \mathrm{H}$ ), 1.20-1.70 (overlapped signals, $6 \mathrm{H})$; 13C-NMR (100 MHz, CDCl3): $\delta$ (ppm) 61.7, 32.9, 32.5, 32.2, 29.3, 27.7, 26.6 [23].

\section{Preparation of compound 3}

A mixture of 1-bromoheptan-7-ol (2), $(7.70 \mathrm{~g}, 39 \mathrm{mmol}), 3,4$-dihydro$2 \mathrm{H}$-pyran (1.5 eq., $5.00 \mathrm{~g}, 58.5 \mathrm{mmol}$ ) and $p$-toluenesulfonic acid $(0.03 \mathrm{eq}$., $222 \mathrm{mg}, 1.17 \mathrm{mmol})$ in dichloromethane $(50 \mathrm{~mL})$ was stirred at room temperature for $12 \mathrm{~h}$. The mixture was diluted with diethyl ether $(300 \mathrm{~mL})$, the organic layer was washed with $2 \times 75 \mathrm{ml}$ water and $75 \mathrm{ml}$ brine. The organic layer was dried over anh. $\mathrm{MgSO}_{4}$ and then evaporated to dryness under reduced pressure. Purification by flash column chromatography (silica gel, eluent $n$-hexane: $\mathrm{Et}_{2} \mathrm{O}=10: 1 \mathrm{v} / \mathrm{v}$, visualization with $\mathrm{H}_{2} \mathrm{SO}_{4}$ in ethanol, $\left.R_{\mathrm{f}}=0.57\right)$ gave the desired compound 2-(7-Bromoheptyloxy)-tetrahydro- $2 \mathrm{H}$ - 
pyran $3(9.00 \mathrm{~g}, 83 \%$ yield with respect to 7-Bromoheptan-1-ol (3) as pure $(>95 \%)$ compound.

2-(7-Bromoheptyloxy)-tetrahydro-2H-pyran 3. Incolor liquid. ${ }^{1} \mathrm{H}$ NMR $\left(400 \mathrm{MHz}, \mathrm{CDCl}_{3}\right): \delta(\mathrm{ppm}) 4.56\left(\mathrm{t},{ }^{3} \mathrm{~J}=4.0 \mathrm{~Hz}, 1 \mathrm{H}\right), 3.89-3.83(\mathrm{~m}, 1 \mathrm{H}), 3.75-$ $3.69(\mathrm{~m}, 1 \mathrm{H}), 3.52-3.46(\mathrm{~m}, 1 \mathrm{H}), 3.41-3.34(\mathrm{~m}, 3 \mathrm{H}), 1.88-1.78$ (overlapped signals, $3 \mathrm{H}), 1.74-1.66(\mathrm{~m}, 1 \mathrm{H}), 1.62-1.29$ (overlapped signals, $12 \mathrm{H}) ;{ }^{13} \mathrm{C}$ NMR (101 MHz, $\left.\mathrm{CDCl}_{3}\right): \delta(\mathrm{ppm}) 99.0,67.7,62.5,34.1,32.9,30.8,29.7$, 28.7, 28.2, 26.2, 25.6,19.8 [7]; MS (El, $70 \mathrm{eV}), \mathrm{m} / \mathrm{z}\left(\mathrm{I}_{\text {rel }}, \%\right): \mathrm{M}^{+}, 279(1)$, $277(<1), 250,252(<1), 223(<1), 207,209(<1), 177,179(<1), 135,137(2)$, 121, 123(1), 97(7), 85(100), 55(40), 41(41), 29(18).

\section{Preparation of compound 4}

Lithium acetylide ethylenediamine complex $(90 \%$ pure, 2 eq., $7.00 \mathrm{~g}$, $0.076 \mathrm{mmol}$ ) was placed in $38 \mathrm{~mL}$ of dry dimethyl sulfoxide (DMSO). The suspension was cooled down to $5-10{ }^{\circ} \mathrm{C}$ and after few minutes 2-(7bromoheptyloxy)-tetrahydro- $2 \mathrm{H}$-pyran (3) $(10.60 \mathrm{~g}, 38 \mathrm{mmol})$ was added dropwise with stirring. The reaction mixture was allowed to warm up at room temperature and stirred for $6 \mathrm{~h}$, after this time, $n$-hexane $(100 \mathrm{~mL})$ was added and the mixture was poured on $100 \mathrm{~g}$ ice. The organic layer was separated and the aqueous layer was extracted with $n$-hexane $(3 \times 100 \mathrm{~mL})$. The combined organic layers were washed to neutrality successively with $100 \mathrm{~mL}$ water, $50 \mathrm{ml}$ dil. aq. hydrochloric acid, $100 \mathrm{ml}$ water and $100 \mathrm{ml}$ brine. The organic layer was dried over anh. $\mathrm{MgSO}_{4}$ and then evaporated to dryness under reduced pressure. Purification by flash column chromatography (silica gel, eluent $n$ hexane: $\mathrm{Et}_{2} \mathrm{O}=10: 1 \mathrm{v} / \mathrm{v}$, visualization with $\mathrm{H}_{2} \mathrm{SO}_{4}$ in ethanol, $\left.R_{\mathrm{f}}=0.50\right)$ gave the desired compound 2-(non-8-ynyloxy)-tetrahydro-2H-pyran (4) (7.6 g, $90 \%$ yield with respect to heptan-1,7-diol) as pure (>95\%) compound.

2-(Non-8-ynyloxy)-tetrahydro-2H-pyran 4. Incolor liquid. ${ }^{1} \mathrm{H}$ NMR $\left(400 \mathrm{MHz}, \mathrm{CDCl}_{3}\right): \delta(\mathrm{ppm})$ 4.57-4.55 (m, 1H), 3.89-3.83 (m, 1H), $3.73(\mathrm{dt}, J$ $=9.6 \mathrm{~Hz}, 6.8 \mathrm{~Hz}, 1 \mathrm{H}), 3.52-3.46(\mathrm{~m}, 1 \mathrm{H}), 3.52-3.46(\mathrm{~m}, 1 \mathrm{H}), 3.37(\mathrm{dt}, J=9.6$ $\mathrm{Hz}, 6.8 \mathrm{~Hz}, 1 \mathrm{H}), 2.19-2.15(\mathrm{~m}, 2 \mathrm{H}), 1.93\left(\mathrm{t},{ }^{3} \mathrm{~J}=2.6 \mathrm{~Hz}, 1 \mathrm{H}\right), 1.88-1.66(\mathrm{~m}$, $2 \mathrm{H}$ ), $1.62-1.23$ (overlapped signals, $13 \mathrm{H}$ ); ${ }^{13} \mathrm{C}$ NMR $\left(101 \mathrm{MHz}, \mathrm{CDCl}_{3}\right.$ ): $\delta$ (ppm) 98.9, 84.9, 68.2, 67.7, 62.5, 30.9, 18.5, 29.8, 29.1, 28.8, 28.5, 26.2, 25.6, 19.8 [24]; MS (El, $70 \mathrm{eV}), \mathrm{m} / \mathrm{z}$ (I $\left.\mathrm{I}_{\text {rel }}, \%\right): \mathrm{M}^{+}-1,223(<1) ; 169(<1) ; 151(<1)$; 128(<1); 115(<1); 101(27); 85(100); 67(27); 55(40); 41(78); 29(27).

\section{Preparation of compound 5}

A solution of $\mathrm{PdCl}_{2}\left(\mathrm{PPh}_{3}\right)_{2}(0.05$ eq., $1.37 \mathrm{~g}, 1.7 \mathrm{mmol})$ in tetrahydrofuran (THF) (234 mL) was added to a solution of (Z)-1,2-dichloroethene (5 eq., $16.66 \mathrm{~g}, 171 \mathrm{mmol}$ ) and terminal alkyne $4(7.7 \mathrm{~g}, 34.37 \mathrm{mmol}$ ) (under argon). 
After 10 min., piperidine ( 3 eq., $8.76 \mathrm{~g}, 103 \mathrm{mmol}$ ) was added. The reaction mixture became clear yellow. After $15 \mathrm{~min}$. Cul (0.1 eq., $0.656 \mathrm{~g}, 3.4 \mathrm{mmol})$ was added. The reaction mixture turned from blue to green, then to orange and finally a white precipitate was formed. The mixture was stirred at room temperature overnight. The solid was filtrated and the precipitate washed with diethyl ether $(3 \times 100 \mathrm{~mL})$ and then poured into water $(100 \mathrm{~mL})$. The combined organic layers were washed with ammonia solution $50 \mathrm{~mL}$ and successively with $100 \mathrm{~mL}$ water, and $100 \mathrm{ml}$ brine. The organic layer was dried over anh. $\mathrm{MgSO}_{4}$ and then evaporated to dryness under reduced pressure. Purification by flash column chromatography (silica gel, eluent $n$-hexane: $\mathrm{Et}_{2} \mathrm{O}=10: 1 \mathrm{v} / \mathrm{v}$, visualization with UV lamp and $\mathrm{H}_{2} \mathrm{SO}_{4}$ in ethanol, $\left.R_{\mathrm{f}}=0.48\right)$ gave the desired compound 2-((Z)-11-chloroundec-10-en-8-ynyloxy)tetrahydro-2H-pyran (5) (6.4 g, 67\% yield with respect to 2-(Hept-6-ynyloxy)tetrahydro-2H-pyran (4) as pure ( $>95 \%$, isomeric purity) compound.

2-((Z)-11-chloroundec-10-en-8-ynyloxy)-tetrahydro-2H-pyran 5. Brown liquid. MS (El, $70 \mathrm{eV}), \mathrm{m} / \mathrm{z}$ (Irel, \%): 283(<1), 269(<1), 249(2), 231(<1), 211(<1), 191(<1), 177(<1), 164(2), 147(2), 131(1,5), 119(7), 105(16), 85(100), 67(20), 55(26), 41(29).

\section{Preparation of compound 7}

The synthesis of compound 7 took place in two steps, two installations were used concurrently. The first step was the formation of Grignard compound (5 eq.). The Grignard compound was prepared from $\mathrm{Mg}$ turnings $(2.18 \mathrm{~g}, 90.48$ $\mathrm{mmol})$, in THF (20 mL) and $\mathrm{I}_{2}$ crystal as an initiator. 1-Bromopropane (6) $(10.74 \mathrm{~g}, 87.35 \mathrm{mmol})$ suspended in THF $(50 \mathrm{~mL})$ was added dropwise. The mixture was refluxed for $3 \mathrm{~h}$. Meanwhile, the other reaction flask was prepared by adding Z-chloroenyne 5 ( $5 \mathrm{~g}, 17.47 \mathrm{mmol}), \mathrm{N}$-methyl-2-pyrrolidone (NMP) (17.5 mL), THF (22.3 mL) and $\mathrm{Fe}(\mathrm{acac})_{3}(0.17 \mathrm{mmol}, 0.01 \mathrm{eq}$.). The formed Grignard compound was poured under argon into a funnel and dropped over the mixture already prepared with protected Z-chloroenyne 5. Heating and darkening of the reaction mixture were observed. The reaction mixture was stirred at room temperature overnight (TLC: eluent $n$-hexane: $\mathrm{Et}_{2} \mathrm{O}=10: 1 \mathrm{v} / \mathrm{v}$, visualization with UV lamp and $\mathrm{H}_{2} \mathrm{SO}_{4}$ in ethanol, $\left.R_{\mathrm{f}}=0.60\right)$. Water $(100 \mathrm{~mL})$ was added, and the organic layer was extracted with $n$-hexane $(3 \times 100 \mathrm{~mL})$. The combined organic layers were washed successively with $100 \mathrm{~mL}$ water and $100 \mathrm{~mL}$ brine, until neutralization, dried over anhydrous $\mathrm{MgSO}_{4}$ and evaporated under reduces pressure. The desired compound 7 (3.8 g) was obtained in $75 \%$ yield and $>95 \%$ isomeric purity.

2-((Z)-Tetradec-10-en-8-ynyloxy)-tetrahydro-2H-pyran 7. Incolor liquid. ${ }^{1} \mathrm{H}$ NMR $\left(400 \mathrm{MHz}, \mathrm{CDCl}_{3}\right): \delta(\mathrm{ppm}) 5.81\left(\mathrm{dt},{ }^{3} \mathrm{~J}=10.7,7.4 \mathrm{~Hz}, 1 \mathrm{H}\right), 4.58-$ $4.56(\mathrm{~m}, 1 \mathrm{H}), 5.44\left(\mathrm{dm},{ }^{3} \mathrm{~J}=10.7 \mathrm{~Hz}, 1 \mathrm{H}\right), 3.89-3.84(\mathrm{~m}, 1 \mathrm{H}), 3.73\left(\mathrm{dt},{ }^{3} \mathrm{~J}=\right.$ 
$9.6 \mathrm{~Hz}, 6.8 \mathrm{~Hz}, 1 \mathrm{H}), 3.52-3.47(\mathrm{~m}, 1 \mathrm{H}), 3.38\left(\mathrm{dt},{ }^{3} \mathrm{~J}=9.6 \mathrm{~Hz}, 6.8 \mathrm{~Hz}, 1 \mathrm{H}\right)$, $2.33\left(\mathrm{td},{ }^{3} \mathrm{~J}=6.9 \mathrm{~Hz}, 2.0 \mathrm{~Hz}, 2 \mathrm{H}\right), 2.26\left(\mathrm{qd},{ }^{3} \mathrm{~J}=7.4 \mathrm{~Hz}, 1.1 \mathrm{~Hz}, 2 \mathrm{H}\right), 1.86-$ $1.68(\mathrm{~m}, 2 \mathrm{H}), 1.62-1.26$ (overlapped signals, $16 \mathrm{H}$ ), $0.92\left(\mathrm{t},{ }^{3} \mathrm{~J}=7.4 \mathrm{~Hz}, 3 \mathrm{H}\right.$ ); ${ }^{13} \mathrm{C}$ NMR $\left(101 \mathrm{MHz}, \mathrm{CDCl}_{3}\right): \delta$ (ppm) 142.5, 109.5, 98.9, 94.4, 77.6, 67.7, $62.5,32.2,30.9,29.8,29.1,28.9(2 \mathrm{C}), 26.3,25.6,22.3,19.8,19.6,13.9 ; \mathrm{MS}$ $(\mathrm{El}, 70 \mathrm{eV}), \mathrm{m} / \mathrm{z}\left(\mathrm{I}_{\text {rel }}, \%\right): \mathrm{M}^{+}$292(<1), 277(<1), 263(<1), 249(<1), 233(<1), 221(<1), 208(<1), 191(1), 177(1), 161(1), 147(2), 133(3), 121(3), 108(14), 85(100), 79(34), 67(23), 55(26), 41(29).

\section{Preparation of compound 8}

To a solution of the protected compound $7,(7.19 \mathrm{mmol})$ in methanol $(68 \mathrm{~mL})$ para-toluenesulfonic acid (PTSA) $(0.1$ eq., $0.7 \mathrm{mmol})$ was added. After stirring for about $12 \mathrm{~h}$ the methanol was evaporated under reduce pressure. The residue was diluted with diethyl ether $(300 \mathrm{~mL})$, washed successively with $75 \mathrm{~mL}$ water, $75 \mathrm{~mL} \mathrm{NaHCO}$ solution and $75 \mathrm{~mL}$ brine, dried over anhydrous $\mathrm{MgSO}_{4}$ and concentrated with a rotary evaporator. It was used in the next steps without purification or was purified on a chromatographic column with silica gel (eluent: $n$-Hex: EtOAc $=2: 1$ ). The product 8 was obtained in $93 \%$ yield and $>95 \%$ isomeric purity.

(Z)-Tetradec-10-en-8-yn-1-ol 8. Incolor liquid. ${ }^{1} \mathrm{H}$ NMR $(400 \mathrm{MHz}$, $\left.\mathrm{CDCl}_{3}\right): \delta(\mathrm{ppm}) 5.81\left(\mathrm{dt},{ }^{3} \mathrm{~J}=10.7,7.4 \mathrm{~Hz}, 1 \mathrm{H}\right), 5.43\left(\mathrm{dm},{ }^{3} \mathrm{~J}=10.7 \mathrm{~Hz}, 1 \mathrm{H}\right)$, $3.63\left(\mathrm{t},{ }^{3} \mathrm{~J}=6.6 \mathrm{~Hz}, 2 \mathrm{H}\right), 2.33\left(\mathrm{td},{ }^{3} \mathrm{~J}=6.9 \mathrm{~Hz}, 1.9 \mathrm{~Hz}, 2 \mathrm{H}\right), 2.25\left(\mathrm{qd},{ }^{3} \mathrm{~J}=7.4\right.$ $\mathrm{Hz}, 1.0 \mathrm{~Hz}, 2 \mathrm{H}$ ), 2.17 (s, 1 H, -OH overlapped), 1.60-1.33 (overlapped signals, $12 \mathrm{H}$ ), 0.92 (t, $\left.{ }^{3} \mathrm{~J}=7.4 \mathrm{~Hz}, 3 \mathrm{H}\right) ;{ }^{13} \mathrm{C}$ NMR $\left(101 \mathrm{MHz}, \mathrm{CDCl}_{3}\right): \delta(\mathrm{ppm}) 142.5$, 109.5, 94.4, 77.6, 63.1, 32.8, 32.2, 29.0, 28.9, 25.8, 22.3, 19.6, 13.9; MS (El, $70 \mathrm{eV}), \mathrm{m} / \mathrm{z}\left(\mathrm{I}_{\text {rel, }} \%\right): \mathrm{M}^{+}, 208(<1) ; 191(<1) ; 179(<1) ; 186(<1) ; 165(1) ; 147(1)$; 133(3); 121(4); 108(36); 91(48); 79(100); 67(36); 55(27); 41(34); 31(22).

\section{Preparation of compound 9'. (Rossi R. method with $\mathrm{LiAlH}_{4}$ ) [13]}

A solution of (Z)-enynol 8 (650 mg, $3.57 \mathrm{mmol})$ in diglyme $(2 \mathrm{~mL})$ under argon was added to a stirred suspension of $\mathrm{LiAlH}_{4}(556 \mathrm{mg}, 4$ eq., $14.6 \mathrm{mmol})$ in diglyme $(10 \mathrm{~mL})$ at room temperature. The reaction mixture was warmed up to $125-130{ }^{\circ} \mathrm{C}$ for $15 \mathrm{~h}$. After cooling the suspension, cold aq. $\mathrm{HCl}(10 \%$, $10 \mathrm{~mL}$ ) was added to decompose the unreacted hydride. Diethyl ether (50 $\mathrm{mL}$ ) was added and the mixture was extracted with diethyl ether $(2 \times 75 \mathrm{~mL})$. The combined organic layers were successively washed with $50 \mathrm{~mL}$ water, $30 \mathrm{~mL} \mathrm{NaHCO}{ }_{3}$ sat., and $50 \mathrm{~mL}$ brine. The organic layer was dried over anh. $\mathrm{MgSO}_{4}$ and then evaporated to dryness under reduced pressure. Purification by flash column chromatography (silica gel, eluent $n$-hexane: EtOAc $=2: 1 \mathrm{v} / \mathrm{v}$, 
visualization with UV lamp and $\mathrm{H}_{2} \mathrm{SO}_{4}$ in ethanol, $\left.R_{\mathrm{f}}=0.66\right)$ gave the desired compound 8,10-tetradecadien-1-ol ( $\left.9^{\circ}\right)(525 \mathrm{mg}, 75 \%$ yield with respect to (Z)Tetradec-10-en-8-yn-1-ol (8) (>90\%, chemical purity) compound.

8,10-Tetradecadien-1-ol 9. Incolor liquid. MS (El, $70 \mathrm{eV}), \mathrm{m} / \mathrm{z}\left(\mathrm{I}_{\mathrm{rel}}, \%\right)$ : $\mathrm{M}^{+}, 210(<1) ; 192(<1) ; 181(<1) ; 167(<1) ; 150(1) ; 135(3) ; 121(9) ; 110(42)$; 95(31); 81(85); 67(100); 54(87); 41(64); 31(26).

\section{Preparation of compound 12}

(Z)-1,2-Dichloroethene (5 eq., $16.66 \mathrm{~g}, 171 \mathrm{mmol}$ ) and 1-pentyne (11) (3.34 g, $34.37 \mathrm{mmol})$ were added under stirring to a solution of catalyst $\mathrm{PdCl}_{2}\left(\mathrm{PPh}_{3}\right)_{2}(0.05 \mathrm{eq}, 1.37 \mathrm{~g}, 1.7 \mathrm{mmol})$ in THF (234 mL). After $10 \mathrm{~min}$. piperidine ( 3 eq., $8.76 \mathrm{~g}, 103 \mathrm{mmol}$ ) was added. The reaction mixture became clear yellow and was stirred for $15 \mathrm{~min}$. Cul $(0.1 \mathrm{eq}, 0.656 \mathrm{~g}, 3.4 \mathrm{mmol})$ was then added. After the reaction mixture turns from blue to green then to orange, a white precipitate was formed and a yellow solution. The mixture was stirred at room temperature overnight and filtered. The precipitate was washed with diethyl ether $(100 \mathrm{~mL})$ and poured into water $(100 \mathrm{~mL})$, and then was extracted with diethyl ether $(3 \times 100 \mathrm{~mL})$. The combined organic layers were successively washed with ammonia solution, water and brine until neutral $\mathrm{pH}$. The combined organic layers were washed with ammonia solution $50 \mathrm{~mL}$ and successively with $100 \mathrm{~mL}$ water, and $100 \mathrm{ml}$ brine. The organic layer was dried over anh. $\mathrm{MgSO}_{4}$ and then evaporated to dryness under reduced pressure. Purification by flash column chromatography (silica gel, eluent $n$-hexane: $\mathrm{Et}_{2} \mathrm{O}=10: 1 \mathrm{v} / \mathrm{v}$, visualization with UV lamp and $\mathrm{H}_{2} \mathrm{SO}_{4}$ in ethanol, $\left.R_{\mathrm{f}}=0.92\right)$ gave the desired compound $12(3 \mathrm{~g}, 68 \%$ yield with respect to 1-pentyne (11) as pure ( $>80 \%$, chemical purity) compound.

(E)-1-Chlorohept-1-en-3-yne 12. Brown liquid. ${ }^{1} \mathrm{H}$ NMR $(400 \mathrm{MHz}$, $\left.\mathrm{CDCl}_{3}\right) \delta(\mathrm{ppm}) 6.45\left(\mathrm{~d},{ }^{3} \mathrm{~J}=13.6 \mathrm{~Hz}, 1 \mathrm{H}\right), 5.94\left(\mathrm{dt},{ }^{3} \mathrm{~J}=13.6 \mathrm{~Hz}, 1 \mathrm{H}\right), 2.29$ (dt, 2H), $1.57(\mathrm{~m}, 2 \mathrm{H}), 1.0(\mathrm{t}, 3 \mathrm{H}) ;{ }^{13} \mathrm{C} \mathrm{NMR}\left(101 \mathrm{MHz}, \mathrm{CDCl}_{3}\right): \delta(\mathrm{ppm}){ }^{13} \mathrm{C}$ NMR (101 MHz, $\left.\mathrm{CDCl}_{3}\right) \delta$ (ppm) 128.7, 114.3, 92.67, 75.78, 21.9, 21.4, 13.5; MS (El, $70 \mathrm{eV}), \mathrm{m} / \mathrm{z}\left(\mathrm{I}_{\text {rel, }} \%\right): \mathrm{M}^{+}, 128(35) ; 115(1) ; 133(7) ; 99(43) ; 91(100) ;$ 86(15); 77(89); 63(69); 61(15); 51(33); 39(33); 29(14).

\section{Preparation of compound 13}

The synthesis of the compound was performed in two steps and two installations were used concurrently. In the first stage, the Grignard -compound was prepared by dropwise addition of a solution of 2-(7-bromoheptyloxy)tetrahydro-2 $\mathrm{H}$-pyran (3) in THF $(20 \mathrm{~mL})$ to a suspension of $\mathrm{Mg}$ turnings $(0.860 \mathrm{~g}, 35.8 \mathrm{mmol})$ in THF $(2 \mathrm{~mL})$ and one crystal of $\mathrm{I}_{2}$ for activation. The 
suspension was refluxed for $3 \mathrm{~h}$. Meanwhile, the other reaction flask was prepared by adding anhydrous $12(1.76 \mathrm{~g}, 13.7 \mathrm{mmol}), \mathrm{NMP}(13.7 \mathrm{~mL})$, THF $(17.5 \mathrm{~mL})$ and $\mathrm{Fe}(\mathrm{acac})_{3}(49 \mathrm{mg}, 0.01 \mathrm{eq}$.). The formed Grignard compound was poured under argon into a funnel and dropped over the mixture already prepared with the protected $(E)$-chloroenyne 12. Heating and darkening of the reaction mixture were observed. The reaction mixture was stirred at room temperature overnight (TLC: eluent $n$-hexane: $\mathrm{Et}_{2} \mathrm{O}=40: 1 \mathrm{v} / \mathrm{v}$, visualization with UV lamp and $\mathrm{H}_{2} \mathrm{SO}_{4}$ in ethanol, $\left.R_{\mathrm{f}}=0.54\right)$. Water $(100 \mathrm{~mL})$ was added, and the organic layer was extracted with $n$-hexane $(3 \times 100 \mathrm{~mL})$. The combined organic layers were washed successively with $100 \mathrm{~mL}$ water and $100 \mathrm{~mL}$ brine, until neutralization, dried over anhydrous $\mathrm{MgSO}_{4}$ and evaporated under reduces pressure. The desired compound $13(2.2 \mathrm{~g})$ was obtained in $55 \%$ yield and $>90 \%$ isomeric purity.

2-((E)-Tetradec-8-en-10-ynyloxy)-tetrahydro-2H-pyran 13. Incolor liquid. MS (EI, $70 \mathrm{eV}), \mathrm{m} / \mathrm{z}\left(\mathrm{I}_{\text {rel }}, \%\right): \mathrm{M}^{+}, 222(1) ; 277(<1) ; 263(<1) ; 249(1)$; $235(<1) ; 219(1) ; 205(<1) ; 191(1) ; 177(1) ; 161(1) ; 147(2) ; 133(4) ; 121(5)$; 105(13); 85(100); 67(22); 55(39); 41(33).

\section{Preparation of compound 14}

To a solution of the protected compound $13(2.2 \mathrm{~g}, 7.5 \mathrm{mmol})$ in methanol $(70 \mathrm{~mL})$ PTSA (0.1 eq., $140 \mathrm{mg}, 0.7 \mathrm{mmol}$ ) was added. The mixture was stirred at rt overnight. The solvent was removed on a rotary evaporator. The residue was diluted with diethyl ether $(200 \mathrm{~mL})$, washed successively with $75 \mathrm{~mL}$ water, $50 \mathrm{~mL} \mathrm{NaHCO} 3$ solution and $75 \mathrm{~mL}$ brine, dried over anhydrous $\mathrm{MgSO}_{4}$ and concentrated with a rotary evaporator. The compound can be used in the next steps without purification or can be purified on a silica gel column (Eluent: $n$-Hex: EtOAc $=2: 1 \mathrm{v} / \mathrm{v}$, visualization with UV lamp and $\mathrm{H}_{2} \mathrm{SO}_{4}$ in ethanol, $R_{\mathrm{f}}=0.72$ ). The deprotected compound 14 was obtained in $93 \%$ yield and $80 \%$ chemical purity.

(E)-Tetradec-8-en-10-yn-1-ol 14. MS (El, $70 \mathrm{eV}), \mathrm{m} / \mathrm{z}$ (Irel, \%): $\mathrm{M}^{+}$, 208(<1); 193(<1); 179(1.5); 165(1); 151(8); 133(3); 121(8); 105(23); 91(56); 79(100); 67(29); 55(34); 41(37); 31(23).

\section{Preparation of compound 9 (Brown CA method, 1970) [21]}

The hydrogenation reaction was performed with $\mathrm{H}_{2}$ at rt and $1 \mathrm{~atm}$. in a personalized installation. The installation is composed by a burette with a three-way valve filled with hydrogen, a water tank to maintain pressure in the burette, a hydrogen bottle, a flow regulator, a magnetic stirred, and a Schlenk flask. First $\mathrm{Ni}(\mathrm{OAc})_{2} \cdot 4 \mathrm{H}_{2} \mathrm{O}(0.1556 \mathrm{~g}, 0.625 \mathrm{mmol})$ was dissolved in ethanol 
$95 \%(95 \mathrm{~mL})$ under stirring (eventually by slight heating), then a solution of $\mathrm{NaBH}_{4}$ $(0.0238 \mathrm{~g}, 0.625 \mathrm{mmol})$ in ethanol $95 \%, 0.625 \mathrm{~mL}$ was added in hydrogen current and the catalyst $\mathrm{NiP}_{2}$ was formed. The reaction mixture became darker and warm. Ethylenediamine $(0.0835 \mathrm{~mL}, 1.39 \mathrm{mmol})$ was added dropwise, and the stirring was stopped. (E)-tetradec-8-en-10-yn-1-ol (14) $(1.05 \mathrm{~g}, 5 \mathrm{mmol})$ was added in one portion and the hydrogen stream was closed. All the external valves were closed, the valve from the burette was opened and the stirring was started until no hydrogen consumption was observed (theoretical consumption $119 \mathrm{ml} \mathrm{H}_{2}$, depending on the temperature and the atmospheric pressure). Then, the valve of the burette was closed and the flow regulating valve was opened. The reaction mixture was diluted with diethyl ether (50 $\mathrm{mL}$ ) and filtered on a G4 filter funnel, the precipitate was washed with 200 $\mathrm{mL}$ diethyl ether. The filtrate was washed successively with $75 \mathrm{~mL}$ water, and $75 \mathrm{~mL}$ brine, to neutral $\mathrm{pH}$. The organic layer was dried over anh. $\mathrm{MgSO}_{4}$ and then evaporated to dryness under reduced pressure. Purification by flash column chromatography (silica gel, eluent $n$-hexane: $\mathrm{Et}_{2} \mathrm{O}=2: 1 \mathrm{v} / \mathrm{v}$, visualization with UV lamp and $\mathrm{H}_{2} \mathrm{SO}_{4}$ in ethanol, $\left.R_{\mathrm{f}}=0.4\right)$ gave the desired compound (8E,10Z)-tetradeca-8,10-dien-1-ol (9) $(0.89 \mathrm{~g}, 85 \%$ yield with respect to compound 14 as pure ( $>95 \%$ isomeric purity) compound.

(8E, 10Z)-Tetradeca-8,10-dien-1-o/ 9 [6]. ${ }^{1} \mathrm{H}$ NMR (400 MHz, $\left.\mathrm{CDCl}_{3}\right)$ $\delta(\mathrm{ppm}) 6.29\left(\mathrm{ddd},{ }^{3} \mathrm{~J}_{\text {trans }}=15.1 \mathrm{~Hz}, 11.0 \mathrm{~Hz}, 0.9 \mathrm{~Hz}, 1 \mathrm{H}\right), 5.94\left(\mathrm{t},{ }^{3} \mathrm{~J}=11.0\right.$ $\mathrm{Hz}, 1 \mathrm{H}), 5.63\left(\mathrm{dt},{ }^{3} J_{\text {trans }}=15.1 \mathrm{~Hz}, 7.3 \mathrm{~Hz}, 1 \mathrm{H}\right), 5.33-5.26(\mathrm{~m}, 1 \mathrm{H}), 3.62(\mathrm{t}$, ${ }^{3} \mathrm{~J}=6.6 \mathrm{~Hz}, 2 \mathrm{H}$ ), 2.16-2.05 (overlapped signals, $4 \mathrm{H}$ ), 1.58-1.49 (overlapped signals, $4 \mathrm{H}$ ), 1.42-1.25 (overlapped signals, $8 \mathrm{H}$ ), $0.91\left(\mathrm{t},{ }^{3} \mathrm{~J}=7.3 \mathrm{~Hz}, 3 \mathrm{H}\right.$ ); ${ }^{13} \mathrm{C}$ NMR $\left(101 \mathrm{MHz}, \mathrm{CDCl}_{3}\right) \delta(\mathrm{ppm}) 134.6,130.0,128.8,125.8,63.1,32.8$, 29.9, 29.45, 29.4, 29.3, 25.8, 23.0, 13.9; MS (El, $70 \mathrm{eV}), \mathrm{m} / \mathrm{z}\left(\mathrm{I}_{\mathrm{rel}}, \%\right): \mathrm{M}^{+}, \mathrm{M}^{+}$, 210(6); 194(<1); 179(<1); 163(<1); 149(1); 135(3); 121(6); 109(10); 95(22); 81(51); 67(100); 55(43); 41(51); 31(22).

\section{Preparation of compound 1}

PCC (1.35 eq., $2.49 \mathrm{~g}$ ) was added to a solution of alcohol 9 or 9' (8.57 $\mathrm{mmol}, 1.8 \mathrm{~g})$ in $\left.\mathrm{CH}_{2} \mathrm{Cl}_{2}\right)(137 \mathrm{~mL})$ at room temperature. The reaction mixture was stirred at room temperature for $3-5 \mathrm{~h}$ and the progress of the reaction was checked by thin-layer chromatography (TLC). $\mathrm{CH}_{2} \mathrm{Cl}_{2}$ was removed by a rotary evaporator and the residue was diluted with $300 \mathrm{~mL}$ diethyl ether, filtered on a G4 filter funnel, washed successively with $75 \mathrm{~mL}$ water and 75 $\mathrm{mL}$ brine until a neutral $\mathrm{pH}$. The organic layer was dried over anh. $\mathrm{MgSO}_{4}$ and then evaporated to dryness under reduced pressure. Purification by flash column chromatography (silica gel, eluent $n$-hexane: $\mathrm{Et}_{2} \mathrm{O}=10: 1 \mathrm{v} / \mathrm{v}$, visualization with UV lamp and $\mathrm{H}_{2} \mathrm{SO}_{4}$ in ethanol, $R_{\mathrm{f}}=0.7$ ) gave the desired 
compound (8E,10Z)-Tetradeca-8,10-dienal (1) $(1.2 \mathrm{~g}, 67 \%$ yield with respect to compound $\mathbf{9}^{\circ}$ or $\mathbf{9}^{\prime}$ as pure (> $95 \%$ isomeric purity or isomers mixture) compounds.

(8E,10Z)-Tetradeca-8, 10-dienal 1 [4, 6]. ${ }^{1} \mathrm{H}$ NMR $\left(400 \mathrm{MHz}, \mathrm{CDCl}_{3}\right)$ $\delta(\mathrm{ppm}) 9.76\left(\mathrm{t},{ }^{3} \mathrm{~J}=1.8 \mathrm{~Hz}, 1 \mathrm{H}\right), 6.29\left(\mathrm{ddd},{ }^{3} \mathrm{~J}_{\text {trans }}=16.0 \mathrm{~Hz}, 1 \mathrm{H}\right), 5.95\left(\mathrm{t},{ }^{3} \mathrm{~J}\right.$ $=10,0 \mathrm{~Hz}, 1 \mathrm{H}), 5.63\left(\mathrm{dt},{ }^{3} J_{\text {trans }}=16 \mathrm{~Hz}, 1 \mathrm{H}\right), 5.35-5.27(\mathrm{~m}, 1 \mathrm{H}), 2.44-2.40$ (m, $2 \mathrm{H}$ ), 2.17-2.04 (overlapped signals, $4 \mathrm{H}), 1.66-1.59(\mathrm{~m}, 2 \mathrm{H}), 1.44-1.23$ (overlapped signals, $8 \mathrm{H}), 0.91\left(\mathrm{t},{ }^{3} \mathrm{~J}=8 \mathrm{~Hz}, 3 \mathrm{H}\right) ;{ }^{13} \mathrm{C} \mathrm{NMR}\left(101 \mathrm{MHz}, \mathrm{CDCl}_{3}\right)$ $\delta$ (ppm) 203.04, 134.44, 130.15, 128.81, 125.94, 44.02, 32.89, 29.88, 29.28, 29.13, 29.03, 23.02, 22.14, 13.93; MS: (El, $70 \mathrm{eV}), \mathrm{m} / \mathrm{z}\left(\mathrm{I}_{\text {rel, }} \%\right): \mathrm{M}^{+}, 208(3)$; $179(<1) ; 165(<1) ; 151(1) ; 135(1) ; 121(4) ; 109(9) ;$ 95(18); 81(41); 67(100); 55(31); 41(48).

\section{ACKNOWLEDGMENTS}

The authors thank Dr. Mircea Varga for his field test work. This work was supported by „Babes-Bolyai” University, „Raluca Ripan” Institute for Research in Chemistry, Pheromone Production Center.

\section{REFERENCES}

1. G. Deschk; N. Dimic; Acta Entomol. Jugosl., 1986, 22, 11-23.

2. T. Perju; I. Oltean; I. Oprean; M. Ecobici; J. Centr. Eur. Agric., 2004, 4, 331-336.

3. D. I. Șandru; Sănătatea plantelor, 1998, 6, 29-34.

4. a. A. Svatoš; B. Kalinová; H. Michal; J. Kindl; O. Hovorka; H. Ivan; Tetrahedron Lett., 1999b, 40, 7011-7014. b. A. Svatoš; B. Kalinová; H. Michal; J. Kindl; O. Hovorka; H. Ivan; IOBC wprs Bulletin, 2001, 24, 5-12.

5. B. Kalinová; A. Svatoŝ; J. Kindl; O. Hovorka; I. Hrdý; J. Kuldová; M. Hoskovec; J. Chem. Ecol., 2003, 29, 387-404.

6. M. Hoskovec; A. Šaman; A. Svatoš; Collect. Czech. Chem. Commun., 2000, 65, 511-523.

7. W. Francke; S. Franke; J. Bergmann; T. Tolasch; M. Subchev; A. Mircheva; T. Toshova; A. Svatos; B. Kalinova; Z. Karpati; G. Szocs; M. Toth; Naturforsch. C: Biosci., 2002, 57, 739-752.

8. R. Marcia de Figueiredo; R. Berner; J. Julis; T. Liu; D. Türp; M. Christmann; J. Org. Chem., 2007, 72, 640-642.

9. L. Gânscă; S. Maxim; I. Ciotlăuș; A. Andreica; I. Oprean; Rev. Roum. Chim., 2011, 56, 895-899.

10. P. Chourreu; O. Guerret; L. Guillonneau; E. Gayon; G. Lefèvre; Org. Process Res. Dev., 2020, 24, 1335-1340.

11. J. Grodner; Tetrahedron, 2009, 65, 1648-1654. 
IULIANA VASIAN, TEODORA FLORIAN, ALEXANDRINA NAN, EMESE GAL, MONICA GORGAN, ȘTEFANIA MARIA TÖTÖS, VASILE FLORIAN, ION OLTEAN

12. K. Sonogashira; Y. Tohda; N. Hagihara; Tetrahedron Lett., 1975, 16, 4467-4470.

13. a. R. Rossi; A. Carpita; Synthesis, 1977, 8, 561-562. b. A. Parenty; J. -M. Campagne; Tetrahedron Lett., 2002, 43, 1231-1233.

14. T. Turki; S. Khamri; H. Amri; J. Soc. Chim. Tunis., 2007, 9, 17-22.

15. W. N. Smith; O. F. Beumel Jr.; Synthesis, 1974, 1, 441-442.

16. G. Cahiez; H. Avedissian; Synthesis, 1998, 8, 1199-1205.

17. A. Fürstner; A. Leitner; M. Méndez; H. Krause; J. Am. Chem. Soc., 2002, 124, 13856-13863.

18. J. H. V. Boom; J. D. M Herschied; C.B. Reese; Synthesis, 1973, 167-169.

19. E.J. Corey; J.W. Suggs; Tetrahedron Lett., 1975, 16, 2647-2650.

20. I. Vasian; I. Oprean; T. Florian; I. Oltean; Ecomoni utilizati in protectia plantelor, Editura Bioflux, 2018, ISBN 978-606-8887-28-9, chapter 1.

21. C. A. Brown; J. Org. Chem., 1970, 35, 1900-1904.

22. H. C. Brown; Organic Syntheses via Boranes; Wiley-Interscience: New York, 1975.

23. A. Singh; M. L. Sharma; J. Singh; Indian Journal of Chemistry, 2010, 49B, 1648-1652.

24. O. Loreau; A. Maret; J. M. Chardigny; J. L. Sébédio; J. P. Noël; Chemistry and Physics of Lipids, 2001, 110, 57-67. 